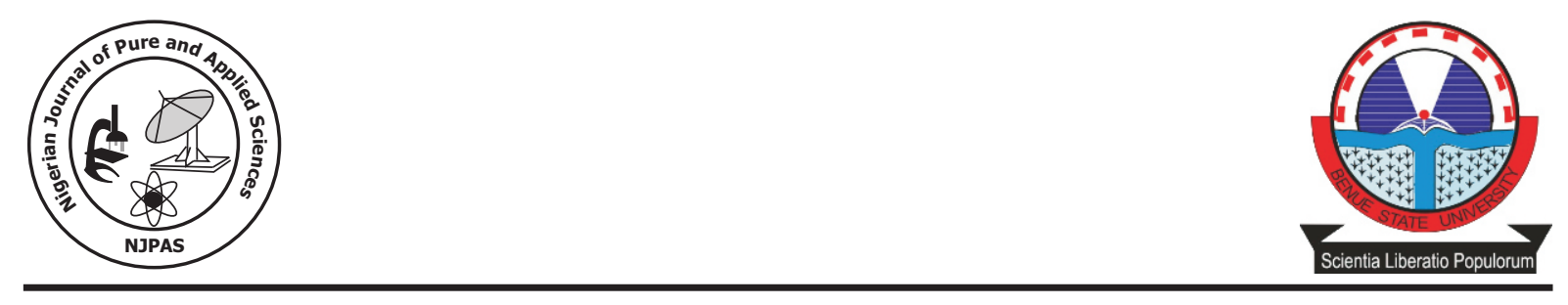

\title{
Fine Particulate Matter Distribution in Makurdi and Otukpo Metropolis, Benue State - Nigeria
}

\author{
Sombo, T., ${ }^{1}$ Agbendeh, A. A. ${ }^{1}$ and . Tsor, J. $\mathrm{O}^{2}$ \\ ${ }^{1}$ Department of Physics, Federal University of Agriculture, P.M.B 2373, Makurdi Nigeria. \\ ${ }^{2}$ Department of Physics, Benue State University P.M.B 102119, Makurdi Nigeria.
}

\begin{abstract}
The suspended fine particulate matter concentrations in Makurdi and Otukpo Metropolis were measured using Haz-Dust Sampler (AMS 95015). The measurements were carried out at major observed emission sources such as residential and traffic related sources. On the average, trafficrelated sources recorded the highest concentration of suspended fine particulate matter in both metropolis with the highest concentration in Otukpo metropolis $\left(594 \mu \mathrm{g} / \mathrm{m}^{3}\right)$. Generally the measured values from all the sources are above World Health Organization (WHO) standards and National Air Quality Standard (150-230 $\mathrm{gg} / \mathrm{m}^{3}$ for $24 \mathrm{hrs}$ ). Results show that Otukpo metropolis has the highest fine particulate concentrations from residential and traffic related sources. In order to keep the suspended fine particulate concentrations from rising above prescribed standards, appropriate control measures are recommended.
\end{abstract}

Corresponding Author: Msendoom@yahoo.com

Key words: Fine Particulate Matter, Pollutants, Health, Environmental effects, Air Pollution.

\section{Introduction}

Air is composed of Nitrogen (78.08\%), Oxygen (20.94\%) and Carbon dioxide $(0.03 \%)$. Air is one of man's most precious resources generally taken for granted until its use is threatened by reduced quality. The quality is often reduced as a result of the presence of pollutants in air. These pollutants are emitted chiefly from our Industrial, Agricultural, Residential and Traffic related sources (Vesilind and Pierce, 1990; Stocham and Yarnate, 1978). Since these pollutants have impact on ambient air quality, prescribed guidelines are set for safe levels of air pollutants tolerable to humans, aquatic organisms and vegetation etc. (FEPA, 1988 and WHO, 1999).

Particulate pollutants consist of many different chemicals that form particles and droplets of widely varying sizes with diverse effects on human health and environment (Miller, 1975; Utah et al., (2005) and Shah et al, (1997). The fine particulate affects public health while the coarse particulates affect public utilities (Shah et al., 1997; Ugwuanyi etal., 2006).

Over $68 \%$ of the gas produced in Nigeria is flared. Between 1976 and 1992 alone, a total of 835 separate oil spill sites were recorded resulting into about 100,000 barrels of oil lost during the period (Ugwuanyi and Sombo, 2005). Most of the spilled oils catch fire and may continue to burn for days such that together with the burning gas and occasionally harmattan dust, forest fires, construction works and burning of fossil fuels like gasoline or coal produce fine particulate matter (Ugwuanyi and Sombo, 2005). 
The pollution of air in Benue State and its effects on both biotic and abiotic components of the environment as reported by researchers such as Ugwuanyi and Obi (2002) and, Ugwuanyi and Sombo (2005) suggest the need for continuing surveillance and monitoring of air quality in the state as a way of seeking a lasting solution to fine particulate pollution problems.

\section{Methodology}

Haz-Dust sampler (AMS 95015) was used to measure the concentration of fine particulate matter after proper calibration of the meter. Measurements were made with the instrument held within the height of $1.5 \mathrm{~m}$ above ground level. The specifications of the Haz-Dust Sampler are given in Table 1.

Table 1: Specifications of Haz-Dust Sampler (AMS 95015)

\begin{tabular}{ll}
\hline Sensing range & $0.01-200 \mathrm{mg} / \mathrm{m}^{3}$ \\
\hline Particles size range & $0.1-50 \theta \mathrm{g} / \mathrm{m}^{3}$ \\
Precision & $\pm 0.002 \mathrm{mg} / \mathrm{m}^{3}$ \\
Accuracy & $\pm 0.10 \%$ \\
Power & $-($ Nicd Battery) \\
Operating time & $>8 \mathrm{hrs}$ (fully charged) \\
Charging time & $10-12$ hrs \\
Signal output & $0-1$ volt \\
Weight & $31 \mathrm{~b}(14.062 \mathrm{~kg})$ \\
\hline
\end{tabular}

\section{RESULTS}

Table I: Concentration of Fine Particulate Matter from Residential sources in Makurdi Metropolis

\begin{tabular}{lll}
\hline Site & Residential Sources & Concentration $\left(\theta \mathrm{g} / \mathrm{m}^{3} \times 10^{3}\right)$ \\
\hline A & Fed. Low Cost North Bank & $0.336 \pm 0.060$ \\
B & Fed. Housing Estate North Bank & $0.369 \pm 0.410$ \\
C & Ankpa Quarters & $0.240 \pm 0.100$ \\
D & Quaralafa Quarters & $0.140 \pm 0.030$ \\
E & Judges Quarters & $0.492 \pm 0.080$ \\
\hline
\end{tabular}

Table II: Concentration of Fine Particulate Matter from Traffic Related Sources in Makurdi Metropolis

\begin{tabular}{lll}
\hline Site & Traffic-Related Sources & Concentration $\left(\mu \mathbf{g} / \mathbf{m}^{\mathbf{3}} \mathbf{x} \mathbf{~ 1 0}^{\mathbf{3}}\right)$ \\
\hline F & Lafia Junction - Wurukum & $0.548 \pm 0.130$ \\
G & Wurukum - High Level & $0.487 \pm 0.080$ \\
H & High Level - Modern Mkt & $0.367 \pm 0.030$ \\
I & High Level - Wadata Mkt & $0.420 \pm 0.120$ \\
J & Wurukum - Gaadi & $0.597 \pm 0.240$ \\
\hline
\end{tabular}

Table III: Concentration of Fine Particulate Matter from Residential Sources in Otukpo Metropolis

\begin{tabular}{lll}
\hline Site & Residential Sources & Concentration $\left(\mu \mathbf{g} / \mathbf{m}^{\mathbf{3}} \mathbf{x} \mathbf{1 0}^{\mathbf{3}}\right)$ \\
\hline $\mathrm{N}$ & GRA & $0.353 \pm 0.180$ \\
$\mathrm{O}$ & Ehupi & $0.692 \pm 0.200$ \\
$\mathrm{P}$ & Zone HB & $0.675 \pm 0.100$ \\
$\mathrm{Q}$ & Ogbonulgahapa & $0.289 \pm 0.080$ \\
$\mathrm{R}$ & Sabon Geri & $0.473 \pm 0.160$ \\
\hline
\end{tabular}


Table IV: Concentration of Fine Particulate Matter from Traffic Related Sources in Otukpo Metropolis

\begin{tabular}{lll}
\hline Site & Traffic - Related Sources & Concentration $\left(\mu \mathbf{g} / \mathbf{m}^{\mathbf{3}} \mathbf{x} \mathbf{1 0}^{\mathbf{3}}\right)$ \\
\hline $\mathrm{S}$ & Ahmadu Bello Way & $0.636 \pm 0.090$ \\
$\mathrm{~T}$ & New Market & $0.697 \pm 0.060$ \\
$\mathrm{U}$ & Nnamdi Azikiwe Way & $0.746 \pm 0.030$ \\
$\mathrm{~V}$ & Akpa Street & $0.490 \pm 0.100$ \\
$\mathrm{~W}$ & Oji Street & $0.399 \pm 0.100$ \\
\hline
\end{tabular}

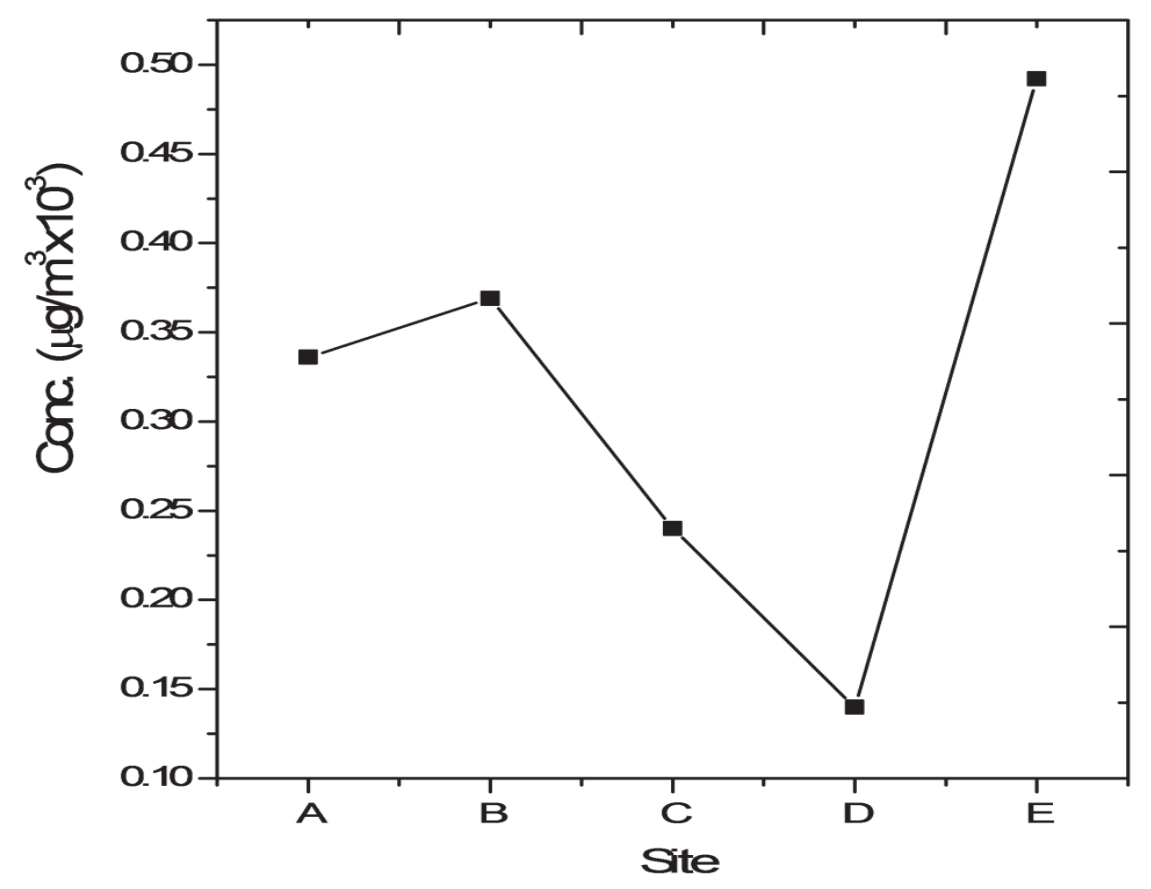

Fig. 1: Variation of Fine Particulate Matter Concentration in some residential related sites in Makurdi.

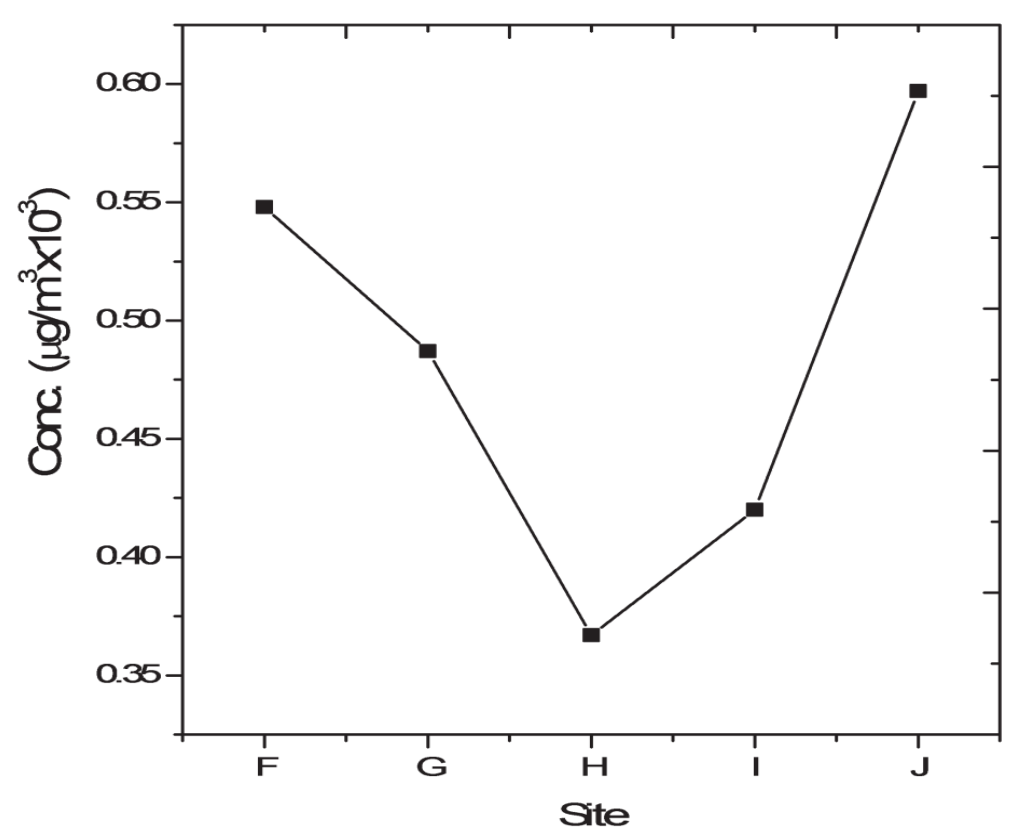

Fig. 2: Variation of Fine Particulate Matter Concentrations due to some Traffic related sites in Makurdi. 


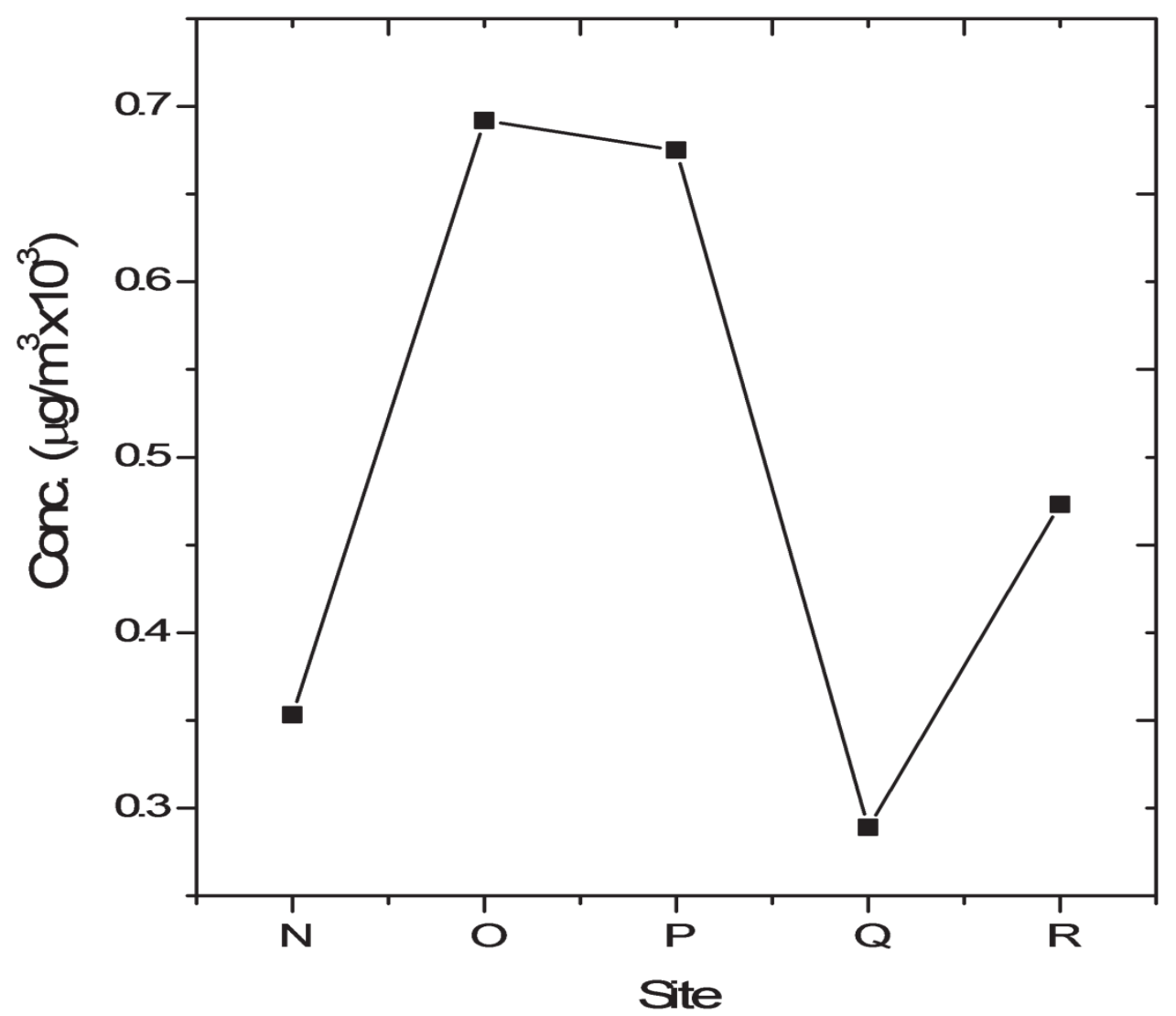

Fig. 3: Variation of Fine Particulate Matter Concentration in some residential related sites in Otukpo

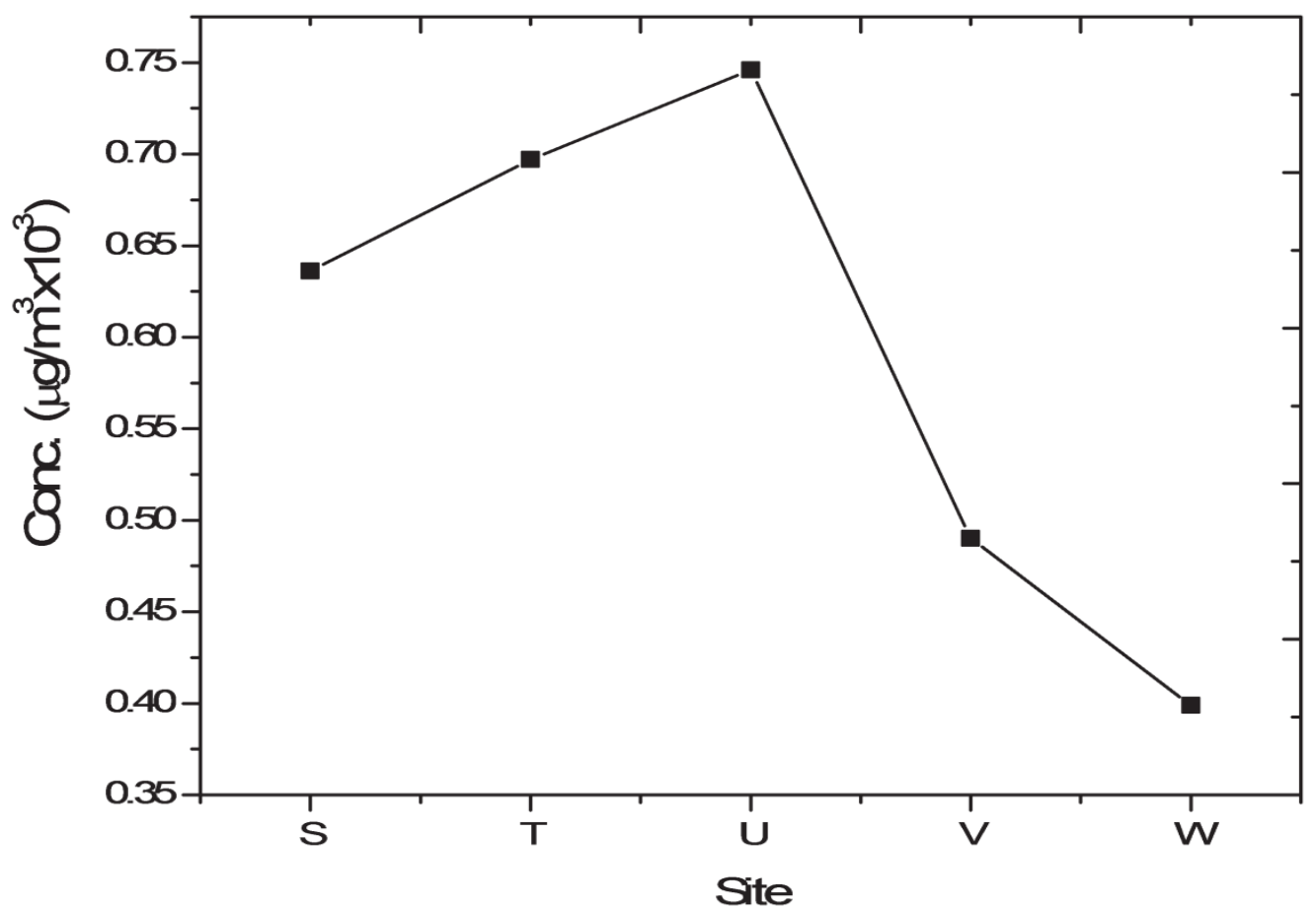

Fig. 4: Variation of Fine Particulate Matter Concentrations due to some Traffic related sites in Otukpo 
The experimental data obtained in this research were analysed statistically using tables and graphs. Figures 1 and 3; and Table 1 and 3 shows that the fine PM concentration ranged from $140 \mu \mathrm{g} / \mathrm{m}^{3} 369 \mu \mathrm{g} / \mathrm{m}^{3}$ in Makurdi metropolis while that for Otukpo ranged from $289 \mu \mathrm{g} / \mathrm{m}^{3}-692 \mu \mathrm{g} / \mathrm{m}^{3}$. This shows a reduction in the concentration within the residential areas in Makurdi and a slight increase in the fine particulate matter concentration in Otukpo Metropolis. This may be as a result of reduced; building construction, refuse bush burning and other household activities in Makurdi metropolis that generate particulate matter. On the other hand, the results from Otukpo may be due to increase in household activities and the fine particulate nature of surface soils in Otukpo metropolis.

The result in Table 2 and 4 presented graphically in figure 2 and 4 respectively that the fine particulate concentration from traffic related sources in Makurdi ranged from 367 $\mu \mathrm{g} / \mathrm{m}^{3}-597 \mu \mathrm{g} / \mathrm{m}^{3}$ while that of Otukpo metropolis ranges from $399 \mu \mathrm{g} / \mathrm{m}^{3}-746 \mu \mathrm{g} / \mathrm{m}^{3}$. In comparison, the fine particulate concentration in Makurdi metropolis from residential sources is lower than the findings $\left(590 \mu \mathrm{g} / \mathrm{m}^{3}\right)$ reported by Ugwuanyi and Obi (2002). However, the concentrations from traffic related sources in some sites is approximately the same $\left(600 \mu \mathrm{g} / \mathrm{m}^{3}\right)$ with findings reported by Ugwuanyi and Obi (2002).

The average concentrations of suspended fine particulate matter obtained for Makurdi and Otukpo graphically presented in figure1-4 revealed that concentrations of suspended fine particulate matter in the two towns is above limits set by World Health Organizations Air Quality Guidelines (WHOAQG) and National Ambient Air Quality Standards (NAAQS) of $150 \mu \mathrm{g} / \mathrm{m}^{3}-230 \mu \mathrm{g} / \mathrm{m}^{3}$ for $24 \mathrm{hrs}$. The concentrations in Otukpo metropolis are relatively high at residential and traffic-related sources. This may be as a result of the nature of Otukpo soil and the untarred condition of roads within the metropolis. Makurdi is relatively clean, this may not be unconnected with the compulsory monthly sanitation exercise strictly observed in the metropolis, good condition of roads (tarred), daily cleaning of major streets and the absence of dust emitting industries such as cement industries and construction works.

\section{Conclusion}

The concentrations of suspended fine particulate matter in the lower atmosphere of both metropolis shows that the lower atmosphere of both towns is heavily polluted. Both Makurdi and Otukpo metropolis are prone to Air-borne diseases (which are particulate- related) such as Asthma, Benign pneurnoconiosis, conjunctivities, Choroditis, Retinitis, skin irritations, Anaemia, Arteriosclerosis, liver and kidney damage and environmental problems such as soiling of building surface and visibility reduction.

\section{References}

FEPA (1988): National Guidelines and Standards for Industrial Effluents, Gaseous Emissions and Hazardous Waste Management in Nigeria. Decree 1988. No.58.

Miller, G.T. Jr. (1975): Environmental Science, Addison Wesly Publishing Company Inc. California. pp 303-362.

Shah, J.J, Nagpa, I. and Brandon, C.J. (1997): Urban Air Quality Management strategy in Asia-Guide book, the World Bank, USA pp. 17-21.

Stocham, J.D. and Yarnate, G. (1978): Sizing particles using the microscope. Ann Arbor Science Publishers, pp. 23-33.

Ugwanyi, J.U and Obi, F.C. (2002): A survey of Health effect of air Pollution on peasant farmers in Benue state, Nigeria. International Journal of Environmental Studies, 59: 665-677.

Ugwuanyi, J.U.; Agbendeh, A.A. and Sombo, T. (2006): PM characterization in some major towns of Benue State, Nigeria. Journal of Information, Communication and Computing Technologies. 183-187. 
Ugwuanyi, J.U and Sombo, T. (2003): Combating Air Pollution: A Challenge to Nigerian Educators. Proceedings of the National Conference on Education for National Growth and Stability. Department of Agricultural and Science Education. University of Agriculture, Makurd, Nigeria. October, 6-9, 2003

Ugwuanyi, J.U and Sombo, T. (2005): Distribution and Intensity of Airborne Diseases in Benue State, Nigerian Journal of Physics. 17: 50-56.
Utah, E. U., Tsor, O. J. and Makama, E. J. (2005). The Harmattan Haze in three Nigerian Cities: Concentrations, size and settling Velocity. Nigerian Journal of Physics, 17:92-98.

Vesilind, P. A and Pierce, J. J. (1990): Environmental Pollution and control, 21 edition, Butterworth publishers, USA pp 252-259.

WHO (1999): Guidelines to Air Pollution control. Online at www.who.org. pp. 13. 